\title{
Medición "in situ" de la permeabilidad al aire del hormigón: status quo
}

\section{Concrete air permeability "in situ”"test: status quo}

\author{
Luis Ebensperger*, Roberto Torrent**1 \\ * Consultor en Hormigón y sus Componentes, Buin. CHILE \\ ** M aterials Advanced Services SRL, Buenos Aires. ARGENTINA \\ Resumen
}

Fecha de recepción: 01/ 10/ 2010 Fecha de aceptación: 01/11/ 2010 PAG. $371-382$

Los autores han estado involucrados en la creación y primeros ensayos y desarrollos del Ilamado "M étodo Torrent" para medir la permeabilidad al aire del hormigón. Transcurridos más de 15 años de ese trabajo fundacional, el artículo presenta una revisión de la evolución y estado de situación del método, incluido como Norma O ficial Suiza en 2003. Se presentan ejemplos de su aplicación en laboratorio y en obras (puentes, túneles, etc.), con datos de valores medidos, provenientes de distintos países del mundo. Se presentan correlaciones entre el coeficiente de permeabilidad al aire kT y otros indicadores de durabilidad, tales como la migración de cloruros (ASTM C1202) y la penetración de agua a presión (EN 12390-8) o por capilaridad. Finalmente se discuten sus perspectivas de uso futuro, como herramienta de control de calidad de estructuras nuevas, con las importantes implicancias que ello acarreará, así como de diagnóstico de estructuras existentes.

Palabras Clave: Hormigón, método Torrent, permeabilidad

Abstract

The authors have been involved in the creation, preliminary tests and development of the "Torrent Method", which is intended to test air permeability in concrete. It's been more than 15 years since such foundational research and, now, this paper presents a review of the evolution and current situation of the Method, included in the Switzerland standards in 2003. Application examples conducted in laboratory and civil works (bridges, tunnels, and so on) are introduced, including data from different countries worldwide. Correlations between the air permeability coefficient kT and other durability indicators, such as chloride migration (ASTM C1202), penetration of water under pressure (EN 12390-8) or capillary action are presented. Finally the future prospective uses are discussed, as quality control tool for new structures, considering relevant implications they would lead to, as well as the diagnosis on existing structures.

Keywords: Concrete, Torrent method, permeability

\section{Introducción}

\section{Introduction}

The more frequent than expected durability problems found in concrete structures, mainly due to reinforcement depassivation and corrosion, chemical attack (e.g. sulfate attack), frost and thaw cycles, have questioned traditional approaches on specification and control of concrete structures.

Whilst the bearing capacity of a structural element is the result of its integral behavior, its durability against aggressive environment conditions basically depends on its protective cover performance, which is relatively thin (20-50 $\mathrm{mm})$, as depicted in Figure 1.

\footnotetext{
1 Autor de correspondencia / Corresponding author:

E-mail: roberto.torrent@holcim.com
} 
This cover layer must protect reinforcement against corrosion induced by carbonation or chlorides and is also the most affected by chemical attacks, frost damage, etc. Unfortunately it is the most affected by bad compaction, finishing and curing practices. Therefore, such essential surface layer turns out to be the one of poorest quality in the whole structural element.

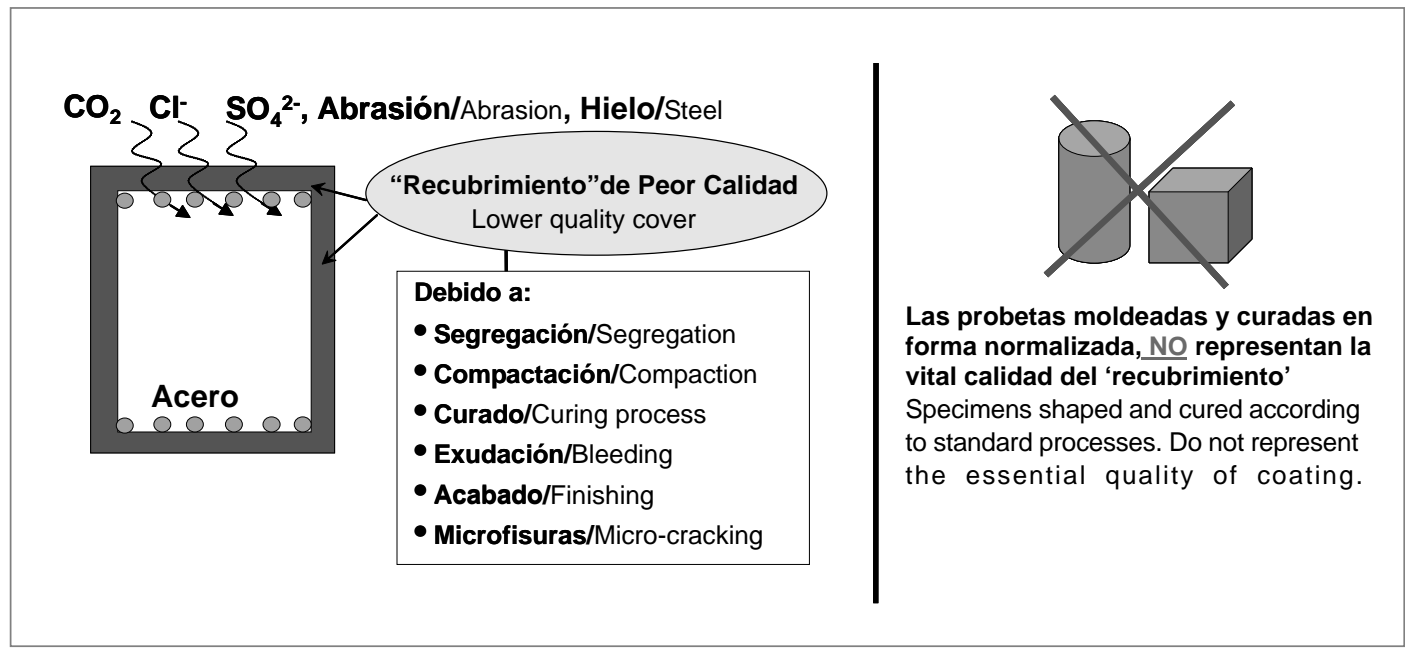

Figura 1. Concepto de Hormigón Superficial (Recubrimiento)

Figure 1. Surface Concrete Concept (Coating)

The classic hardened concrete specifications and control criteria are almost exclusively based on results from cast test specimens and, specially as far as durability is concerned, by establishing maximum limits to the water/cement ratio.

It is now clear why this approach has failed in guaranteeing durability: the results of fast test specimens could never represent the surface layer quality, because those are prepared and cured in a very different way from the structure actual conditions. On the other hand, the water/cement ratio is hard to verify in practice and, laters, it has been questioned as a durability indicator.

So, the actual quality of such essential layer is ignored, which explains to a great extent the unsatisfactory performance of several structures, from a durability point of view. The basic knowledge that cover concrete, having different properties than those in the center of the structure, goes back to the 80's (Kreijger, 1986; N ew man, 
1987; Meyer 1987) and was included by the Model Code (CEB-FIB, 1990), which in 1990 quoted:

"There is no generally accepted method to characterize the pore structure of concrete and to relate it to its durability. However, several experimental investigations have indicated that concrete permeability both with respect to air and to water is an excellent measure for the resistance of concrete against the ingress of aggressive media in the gaseous or in the liquid satet and thus is a measure of the potential durability of a particular concrete."

"There are at present no generally accepted methods for a rapid determination of concrete permeability and of limiting values for the permeability of concrete exposed to different environmental conditions. However, it is likely that such methods will become available in the future allowing the classification of concrete on the basis of its permeability. Requirements for concrete permeability may then be postulated; they would depend on exposure classes i.e. environmental conditions to which the structure is exponsed."

"Though concrete of a high strenght class is in most instances more durable than concrete of a lower strenght class, compressive strength per se is not a complete measure of concrete durability, because durability primarily depends on the properties of the surface layers of a concrete member which have only a limited effect on concrete compressive strength."

The quality of cover concrete is the result, on one hand, of the chosen mix design and, on the other hand, the care applied during concrete processing (placement, compaction, finishing, curing, etc.) Then, it is obvious that cast test specimens, processed under very different conditions from those in structural elements, would never provide a real and representative picture of the cover concrete real quality. Therefore, the only possibility is to measure it directly on the structure, preferably "in situ" by using non-destructive methods or on cover drilled from it.

The so called "Torrent Method" employed to measure cover concrete air permeability, in a completely non-destructive way, aims directly to it: to specify and control the cover concrete quality in a finished structure.

18 years from its creation, this paper presents a review on shows the method's evolution and current situation, included as a Switzerland Standard M ethod in 2003. 


\section{2. "Torrent method" description}

The layout of the device is sketched in

Figure 2. Its two distinctive characteristics are:

a) A double-chamber cell, based on the guard-ring principle. It consists of an internal camber $\boldsymbol{i}$ and an external chamber $\boldsymbol{e}$.

b) A membrane pressure regulator, which function is to always keep both chambers at the same pressure $\left(P_{i}=P_{e}\right)$.

This device operates as follows: valves 1 is closed and valve 2 is opened creating a vacuum inside both chambers by means of vacuum pump. When pressure $\mathrm{P}_{\mathrm{i}}$ drops to $\sim 30 \mathrm{mbar}$ then valve 2 closes, from this moment the pump can only work (when the regulator allows it) on the external chamber, so as to equilibrate at any moment the pressure in both chambers. In this way the excess of air indirectly entering the external chamber will be evacuated by the external chamber. Thus, a basically unidirectional air flow into the central chamber is achieved (see flow lines in Figure 2), and not affected by the ingress of spurious air because of a deficient sealing of the external chamber or through the most permeable surface "skin".

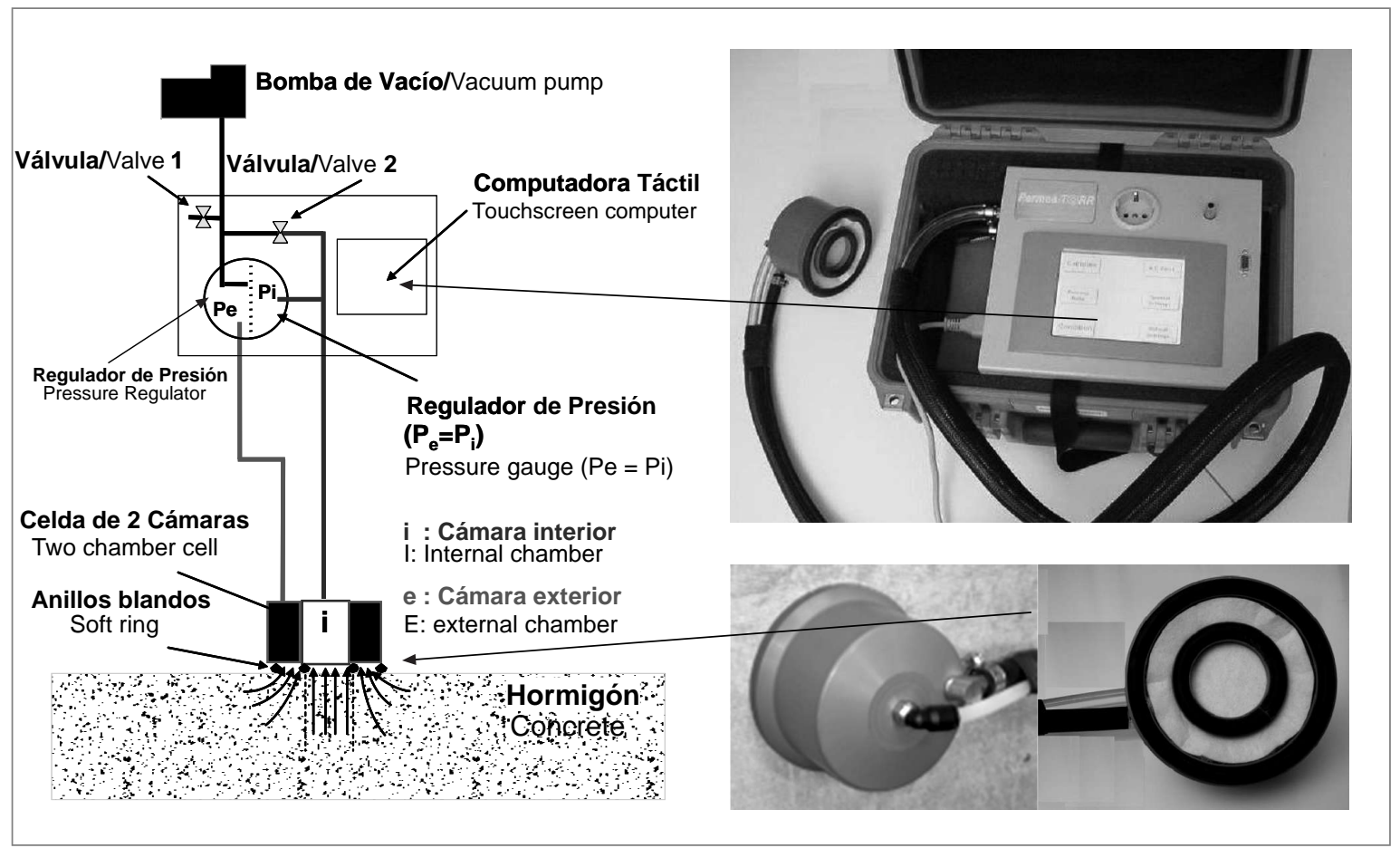

Figura 2. Esquema y detalles del Método Torrent

Figure 2. Scheme and D etails of Torrent M ethod 
The evolution of Pi Pressure is measured after $60 \mathrm{sec}$. by a pressure gauge commanded by a microprocessor with a built chronometer. The microprocessor stores the information and automatically calculates the air permeability coefficient value $\mathrm{kT}\left(\mathrm{m}^{2}\right)$, that is displayer at the end of the test. The end of the test occurs when the pressure of internal chamber $\mathrm{P}_{\mathrm{i}}$ rises by 20 mbar or, in cases of highly permeable concrete, after $360 \mathrm{~s}$. from the beginning of the test. Consequently, depending on the concrete permeability, the test may take from 2 to 6 minutes. The microprocessor is well able to store tests' data and the information can be sent to a PC for further analysis and file.

The function of valve 1 is to restore the system for a new test by ventilating it with air at atmospheric pressure.

Since the problem geometry of the method is well defined, by means of a theoretical model, it is possible to calculate the permeability coefficient by means of equation 1, as described in (Torrent and Frenzer, 1995).

The kT knowledge allows the estimation of concrete depth affected by the test, which is also indicated by the device.

The air permeability kT is very sensitive to the cover concrete microstructure, comprising some 6 orders of magnitude $\left(0.001\right.$ to $\left.10010^{-16} \mathrm{~m}^{2}\right)$. Table 1 shows the classification of concrete permeability (ages from 28 to 180 days) in function of $k T$.

$$
k_{T}=\left(\frac{V_{c}}{A}\right)^{2} \frac{\mu}{2 \varepsilon p_{a}}\left(\frac{\ln \left(\frac{p_{a}+p}{p_{a}-p} \frac{p_{a}-p_{o}}{p_{a}+p_{o}}\right)}{\sqrt{t}-\sqrt{t_{o}}}\right)^{2}
$$

Where:

kT: coefficient of air permeability $\left[\mathrm{m}^{2}\right]$

$V_{c}$ : volume of inner chamber $\left[\mathrm{m}^{3}\right]$

A: surface area of inner chamber [ $\left.\mathrm{m}^{2}\right]$

$\mu$ : dynamic viscosity of air [ $\left.\mathrm{Ns} / \mathrm{m}^{2}\right]$

$\varepsilon:$ porosity of concrete [-]

$\mathrm{p}_{\mathrm{a}}$ : atmospheric pressure $\left[\mathrm{N} / \mathrm{m}^{2}\right]$

$p_{0}$ : inner chamber pressure at initiation of test $\left(t_{0}=60 \mathrm{~s}\right)$ $\left[\mathrm{N} / \mathrm{m}^{2}\right]$

$\mathrm{p}$ : inner chamber pressure at end of test ( $<360 \mathrm{~s}$ ) $\left[\mathrm{N} / \mathrm{m}^{2}\right]$ 
Tabla 1. Clasificación de la permeabilidad del hormigón en función de kT Table 1. Classification of concrete permeability in function of kT

\begin{tabular}{||c|c|c||}
\hline Class & $\mathrm{kT}\left(10^{-16} \mathrm{~m}^{2}\right)$ & Permeability \\
\hline PK1 & $<0.01$ & Very Low \\
\hline PK2 & $0.01-0.1$ & Low \\
\hline PK3 & $0.1-1.0$ & Moderate \\
\hline PK4 & $1.0-10$ & High \\
\hline PK5 & $>10$ & Very High \\
\hline
\end{tabular}

\section{Milestones in the development, application and standardization of the method}

\begin{tabular}{|c|c|c|}
\hline Año/Year & Evento/Event & Ref. \\
\hline 1990 & $\begin{array}{l}\text { Torrent desarrolla el método en "Holderbank Management \& Consulting Ltd." (HMC), Suiza, construyendo el } 1^{\circ} \text { prototipo } \\
\text { Torrent develops the method at "Holderbank M anagement \& Consulting Ltd." Switzerland, creating the first prototype }\end{array}$ & Torrent (1992) \\
\hline $91-93$ & $\begin{array}{l}\text { Torrent y Ebensperger (HMC) desarrollan un exhaustivo programa de ensayos de laboratorio, financiado por el } \\
\text { Departamento Federal de Rutas Suizo, evaluando el desempeño de un mejorado } 2^{\circ} \text { prototipo. Primeras pruebas tentativas } \\
\text { "in situ". } \\
\text { Propuesta de combinar el método con la medición de resistividad eléctrica. } \\
\text { Torrent and Ebensperger (HMC) develop an exhaustive laboratory tests program, financed by the Swiss Roads Federal } \\
\text { Department, evaluating the improved performance of a second prototype. First preliminary "in situ" tests. } \\
\text { Proposal of combining the method with an electric resistivity measurement. }\end{array}$ & Torrent y Ebensperger (1993) \\
\hline 1993 & $\begin{array}{l}\text { Proceq S.A. desarrolla un } 3^{\circ} \text { prototipo con vistas a su comercialización } \\
\text { Proceq S.A, develops a third prototype intended for comercialization. }\end{array}$ & \\
\hline $93-95$ & $\begin{array}{l}\text { Torrent y Frenzer (HMC) desarrollan un programa de ensayos en obra (túnel y varios puentes), financiado por el } \\
\text { Departamento Federal Vial Suizo, usando el } 2^{\circ} \text { y } 3^{\circ} \text { prototipo. La fórmula definitiva para calcular la permeabilidad es } \\
\text { mejorada y se perfecciona el uso combinado con la resistividad eléctrica mediante un nomograma } \\
\text { Torrent and Frenzer (HMC) develop a test program in job sites (tunnels and several bridges) financed by the Swiss Road } \\
\text { Federal Department, employing prototypes } 2 \text { and } 3 \text {. The final permeability calculation formula is improved and also } \\
\text { the combined use with the electric strength is improved by means of a Nomograph. }\end{array}$ & Torrent y Frenzer (1995) \\
\hline 1995 & $\begin{array}{l}\text { Proceq S.A. lanza al mercado un producto comercial en base al } 3^{\circ} \text { prototipo designado "Torrent Permeability Tester" } \\
\text { Proceq S.A. launches into the market a commercial product based on the third prototype named "Torrent Permeability } \\
\text { Tester" }\end{array}$ & \\
\hline 2003 & $\begin{array}{l}\text { Normalización del método en Suiza: SIA 262/1-E: "Permeabilidad al aire en las estructuras" } \\
\text { Regulation of the method in Switzerland: SIA 262/1-E, "Air Permeability in Structures" }\end{array}$ & SIA 262/1, 2003 \\
\hline 2004 & $\begin{array}{l}\text { Primera aplicación para medir la permeabilidad de rocas } \\
\text { First application able to measure rocks permeability. }\end{array}$ & Bueno, 2004 \\
\hline 2005 & $\begin{array}{l}\text { Recomendación RILEM 189-NEC. Mejor desempeño en un ensayo comparativo con otros métodos } \\
\text { RILEM 189-NEC Recommendation. Improved performance of a comparative test using other methods. }\end{array}$ & Romer, 2005 \\
\hline 2008 & $\begin{array}{l}\text { Materials Advanced Services S.R.L. lanza al mercado un instrumento de última generación designado "Permea-TO RR" } \\
\text { Material Advanced Services S.R.L. launches into the market a state of the art device named "Permea-TO RR" }\end{array}$ & \\
\hline & $\begin{array}{l}\text { Más de } 80 \text { publicaciones referidas a aplicaciones del "Método Torrent" en } 15 \text { países } \\
\text { More than } 80 \text { publications referred to Torrent Method applications in } 15 \text { countries }\end{array}$ & Torrent, 2008a \\
\hline
\end{tabular}




\section{Correlation with other transport tests}

Torrent (2008b) conducted a detailed literature review, extracting comparative data from $\mathrm{kT}$ and from other well known methods employed to measure transport phenomena in concrete.

Figures 3 to 7 show the obtained results. Further information on the sources can be found in (Torrent, 2008a and 2008b).

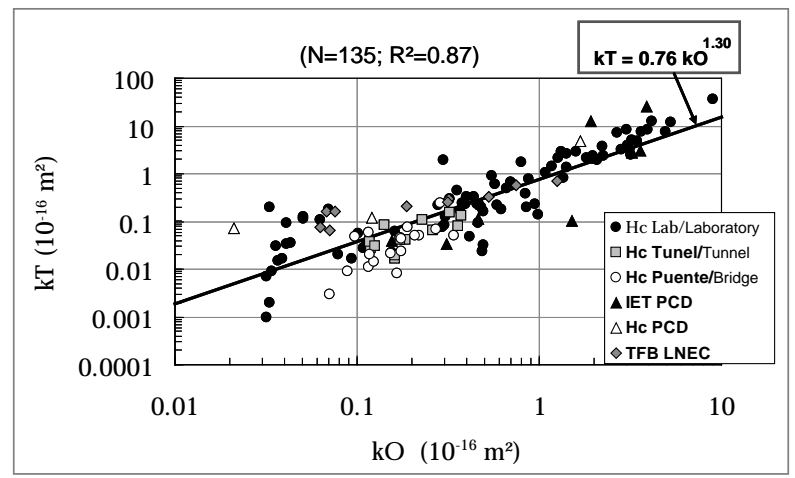

Figura 3. Correlación entre kT y la permeabilidad al oxígeno (Recomendación RILEM PCD-116) Figure 3. Correlation between kT and oxygen permeability (Recommendation RILEM PCD-116)

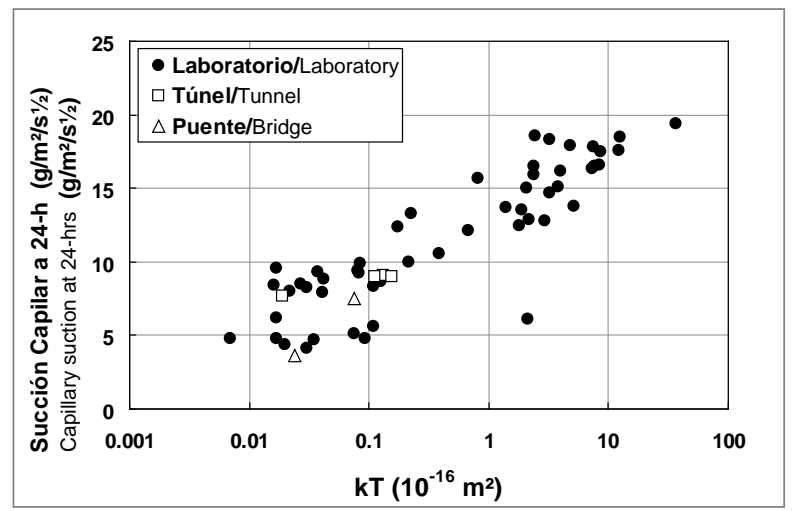

Figura 4. Correlación entre kT y el coeficiente de succión capilar a 24 h (SIA 262/1A)

Figura 4. Correlation between kT and the capillary suction coefficient at 24-hrs (SIA 262/1A)

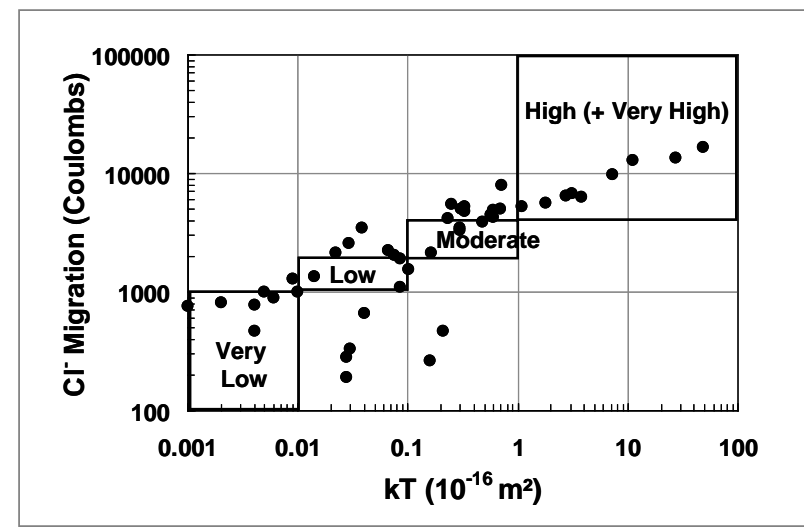

Figura 5. Correlación entre kT y la migración de cloruros (ASTM C1202)

Figura 5. Correlation between kT and chloride migration (ASTM C1202) 


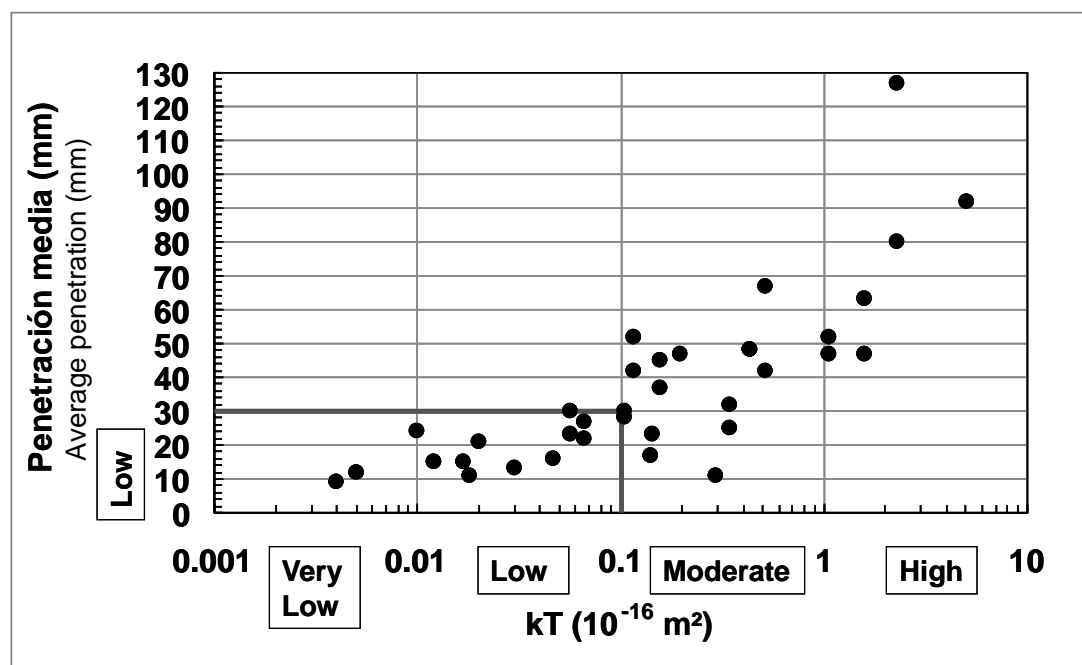

Figura 6. Correlación entre kT y la penetración de agua bajo presión (EN 12390-8 / DIN 1048) Figura 6. Correlation between kT and water penetration under pressure (EN 12390-8/DIN 1048)

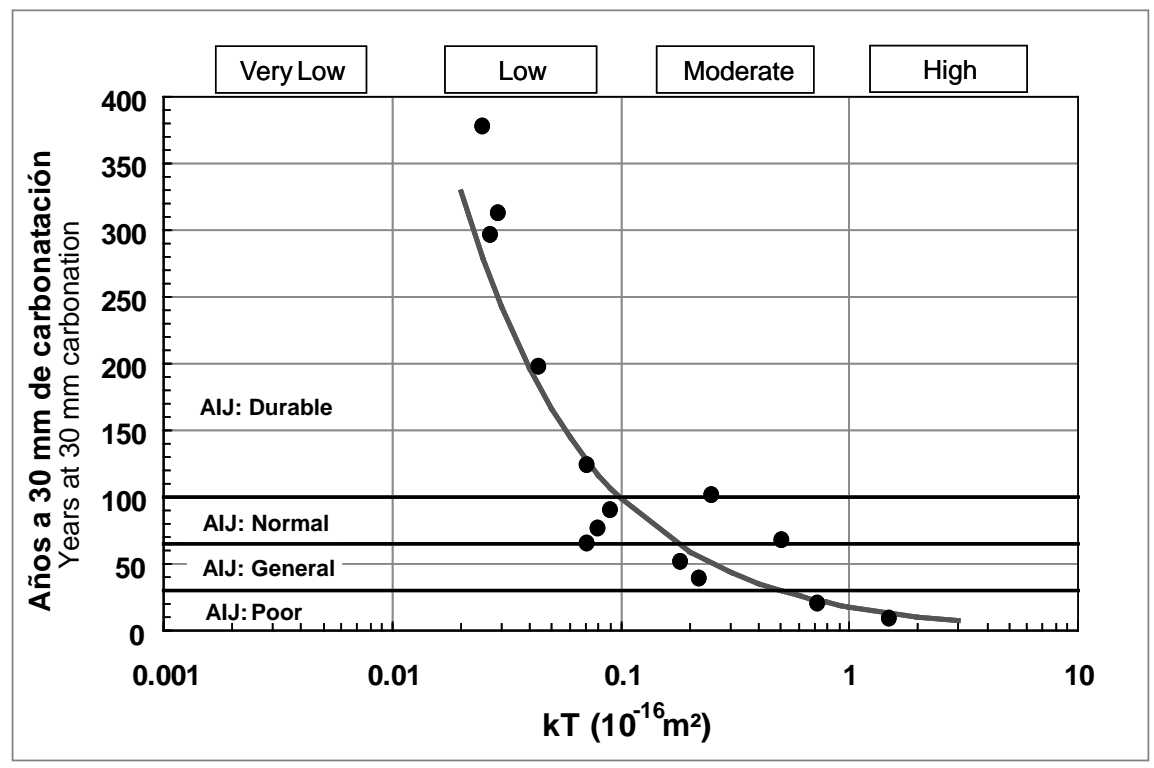

Figura 7. Correlación entre kT y la edad para alcanzar 30 mm de carbonatación, extrapolada en base a ensayos a 4 años con la ley de la raíz cuadrada

Figura 7. Correlation between $\mathrm{kT}$ and the age required to reach $30 \mathrm{~mm}$ carbonation, extrapolated according to 4 years-old tests with the square-root law

Besides the good existing correlation, remarkable considering the diversity of transport mechanisms involved and the wide diversity of data sources, it is important to highlight that the permeability classes based on kT (see Table 1) correspond quite well with the ones established by the Standard ASTM C1202 (Figure 5), Standard EN 12390-8 (Figure 6) and with the AIJ, established by the Japanese Standards (Figure 7).

It can be concluded that $\mathrm{kT}$ value is a good durability indicator regarding the intrusion of aggressive agents in the structures. 


\section{Application of the method to the control of new}

The new Swiss Code of Concrete Construction

[SIA 262 (2003)] states:

a) "with regard to durability, the quality of the cover concrete is of particular importance"

b) "the impermeability of the cover concrete shall be checked, by means of permeability tests (e.g. air permeability measurements), on the structure or on cores taken from the structure"

In 2009 the emission of the standard by the Swiss Regulation Organization SIA was expected, which is a detailed document that specifies where and when $k T$ measurements are to be made and, how the $k T$ values shall be specified and its compliance to be controlled at work sites. This document is based on the work developed by a specialist commission in a project financed by the Swiss Road and Traffic Federal Department (ASTRA, 2009).

\section{Application of the method to the diagnosis of a existing structures}

Even though the "Torrent Method" has been developed considering its preventive role (ensuring the service life of new structures), several application cases have been reported for existing structures.

Figure 8 shows $k T$ comparative data, measured directly on two Swiss bridges 30 and 60 years-old, with the carbonation depth measured with phenolphthalein on cover drilled from the same places (Torrent and Frenzer, 1995).

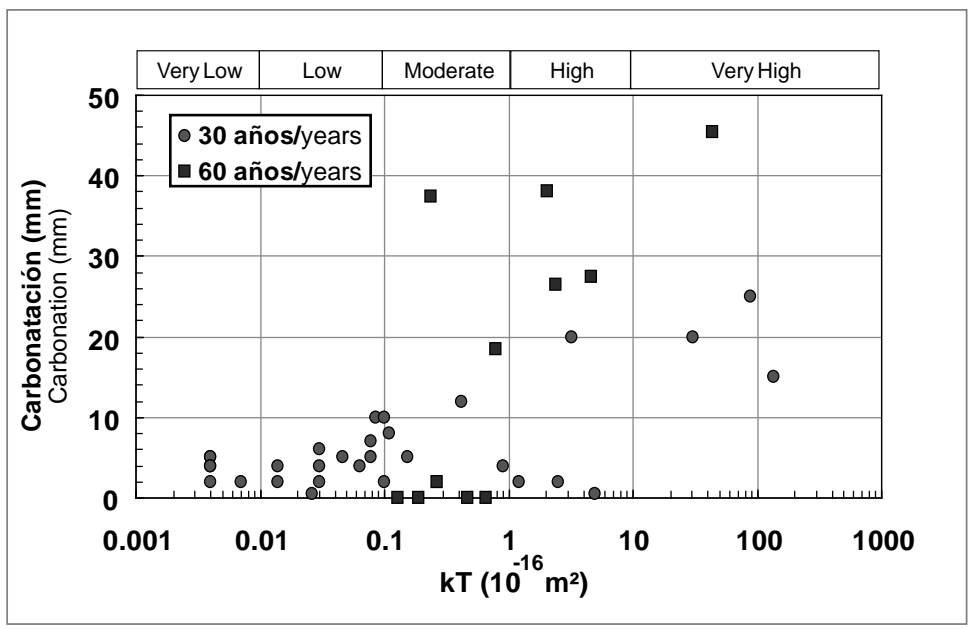

Figura 8. Valores de kT y profundidad de carbonatación en antiguos puentes suizos Figure 8. kT values and carbonation depth in old Swiss bridges 
Figure 9 corresponds to a very similar research conducted in another 30 years-old Swiss bridge, where besides carbonation, the content of chlorides at $25 \mathrm{~mm}$ depth was measured (Jacobs, 2008).

Figure 10 shows kT value contours measured on a Japanese 6 years-old wall, which has one side treated with coating and the other side untreated (Q uoc and Kishi, 2006). It is quite interesting that KT values on the treated side are an order of magnitude lower than on the untreated side and a uniform distribution, except in localized zones where a detailed inspection revealed faults of the coating.

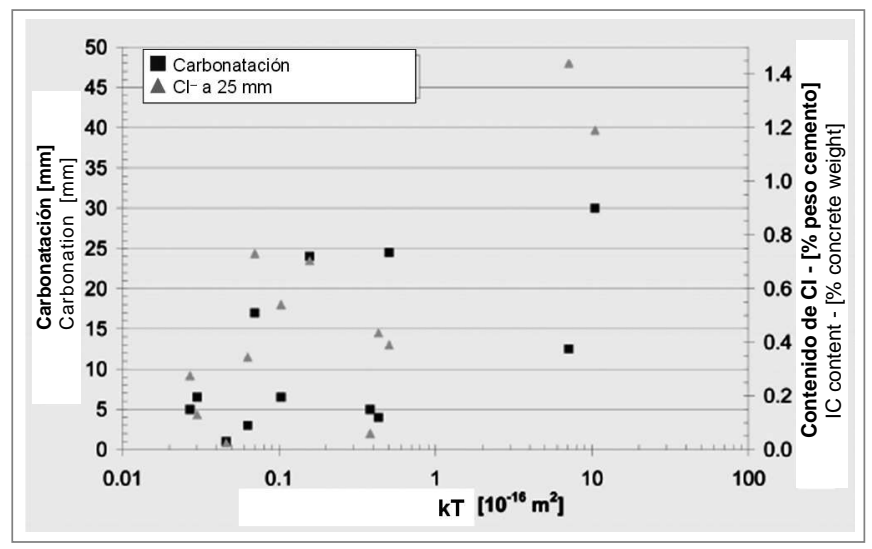

Figura 9. Valores de kT, carbonatación y contenido de cloruros en un puente suizo de 30 años

Figure 9. KT values, carbonation and chloride content in a Swiss 30 years-old bridge

a) cara tratada/treated side $(\mathrm{kTgm}=0.4310-16 \mathrm{~m} 2)$

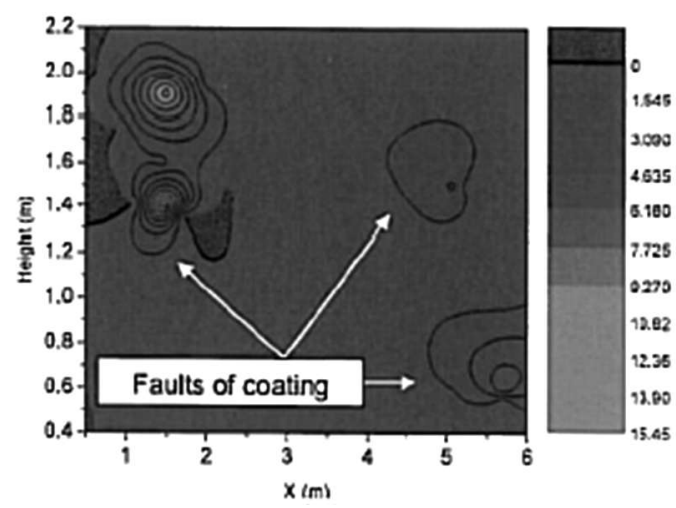

b) cara no tratada/untreated side $(\mathrm{kTgm}=4.96$ 10-16 m2)

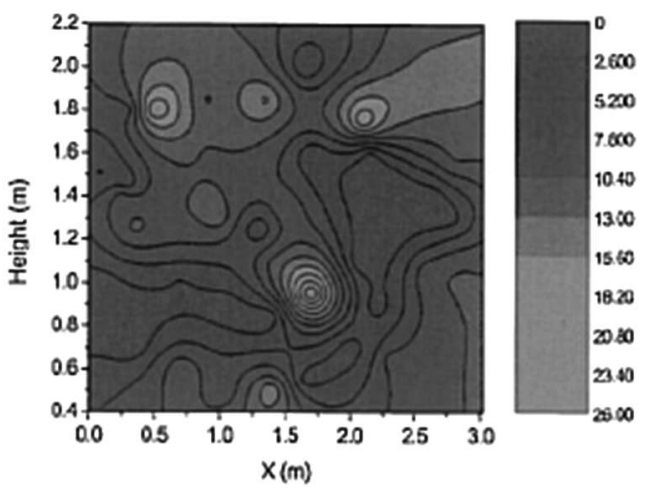

Figura 10. Contornos de valores de kT, medidos en dos caras de un muro de 6 años Figure 10. kT Value Contours, measured at both sides of a 6 years-old wall 


\section{Conclusions}

This tour along the evolution and current situation of "Torrent Method" allow us to draw the following conclusions:

- The method is suitable to measure the resistance of the concrete cover against the intrusion of aggressive agents (by diverse mechanisms) that affect structures durability.

- It correlates very well with other methods to measure transport phenomena in concrete, having the advantage of being faster and completely non-destructive.

- Its inclusion in Swiss Standards SIA 262 and 262/1 constitutes a foundational step towards the use of performance concepts to specify and control structures durability, with the following advantages:

o By controlling the finished product (the structure on site), it consolidates a new mindset, performance oriented, in all the parties involved in the construction process (construction and concrete companies, material suppliers, etc).

o It tends to erradicate bad practices (uncontrolled water addition to concrete, poor compaction, lack of curing, water or cement addition for floor finishing, etc).

o It stimulates the use of innovative solutions to improve the quality of cover concrete (permeable membranes for formworks, vacuum "dewatering" of slabs and the use of special concretes, such as self-compacting, high performance or self-curing concretes, etc.)

- It constitutes a useful tool for the diagnosis of structures conditions, by identifying the most vulnerable areas where other studies may be conducted.

- Some pioneering work indicates the possibility of employing this method on other porous materials, such as stones (monument conservation), tiles or ceramic tiles. 


\section{Referencias / References}

ASTRA (2009), ASTRA empfehlungen zur Q ualitätskontrolle von Beton mit Luftpermeabilitätsmessungen, O ffice Fédéral des Routes, VSS Report 641, December 2009, Bern, Switzerland. Downloadable from http://partnershop.vss.ch/downloadAnhang.aspx?ID=8e2c2936-d3a4-43d7-8dd6-b0706e9a65fb\&ID Sprache=1

Bueno V. (2004), “Estudio de Factibilidad de un Nuevo Ensayo de Permeabilidad en Rocas” (in Spanish), Univ. del Zulia, Maracaibo, Venezuela, 0 ct. 2004, $88 \mathrm{p}$.

CEB-FIP (1990), MODEL CODE 1990, Final Draft, Section d.5.3: "Classification by Durability", CEB Bulletin d'Information N 205, Lausanne, July 1991.

Jacobs F. (2008), "Beton zerstörungsfrei untersuchen" (in German), der Bauingenieur, n.3, pp. $24-27$. Kreijger P.C (1984), "The skin of concrete. Composition and properties", Mater. \& Struct. 17(100) $275-283$. Meyer A. (1987), "The importance of the surface layer for the durability of concrete structures", ACI SP-100, v.1, 49-61. N ewman K. (1987), "Labcrete, realcrete and hypocrete. Where we can expect the next major durability problems", ACI SP-100, v.2, 1259-1283.

Quoc P.H.D. y Kishi T. (2006), “M easurement of air permeation property of cover concrete”, Proc. JSCE Annual Meeting, v. 61, Disk 2, 2 p.

Romer M. (2008), RILEM Recommendation TC 189-NEC "Comparative test - Part I - Comparative test of penetrability methods", Materials \& Structures, v38, Dec 2005, pp. 895 - 906, updated in v41, Apr 2008, pp. 443-447.

SIA 262 (2003), Swiss Standard: “Concrete Construction”, part of Swiss structural codes (German, French, Italian and English versions available).

SIA 262/1 (2003), N orme Suisse: "Construction en béton - Spécifications complémentaires", Annexe E: Perméabilité à l'air dans les Structures, pp. 30-31 (in German and French)

Torrent R. J. (1992), "A two-chamber vacuum cell for measuring the coefficient of air-permeability of the concrete cover on site", Materials \& Structures, v. 25, n.150, pp. 358-365.

Torrent R. (2008a), "N on-destructive Site Air-Permeability Test - Annotated Bibliography", Materials Advanced Services Ltd., Buenos Aires, O ctober 2008. www.m-a-s.com.ar

Torrent R. (2008b), “N on-destructive Site Air-Permeability Test - Relation with other transport test methods”, Materials Advanced Services Ltd., Buenos Aires, O ctober 2008. www.m-a-s.com.ar

Torrent R. y Ebensperger L. (1993), “Studie über M ethoden zur M essung und Beurteilung der Kennwerte des Ü berdeckungsbetons auf der Baustelle” (in German), Office Fédéral des Routes, Rapport No. 506, Bern, Suiza, 119 p. Torrent R. y Frenzer G. (1995), "Methoden zur M essung und Beurteilung der Kennwerte des U eberdeckungsbetons auf der Baustelle", Report N516, O ffice Fédéral des Routes, Zürich. 